\title{
Salt Trading in Deli: Relationship between Karo and Coastal Area in $19^{\text {th }}$ Century
}

\author{
Suprayitno', Ratna $^{2}$, Handoko ${ }^{3}$ \\ ${ }^{1,2,3}$ Universitas Sumatera Utara, Indonesia \\ suprayitno@usu.ac.id
}

\begin{abstract}
In the East Coast region of Sumatra trade patterns between inland and coastal areas have occurred since the pre-colonial period. If we pull back, the Coastal region and the interior have been trading since the 14th century; this can be seen from the archaeological findings of ancient foreign ceramics in Kabanjahe. In the 19th century, orientalists have stepped on East Sumatra. In their visits and reports, orientalists say that there has been a trade relationship between the people in the community with the coastal community. This indicates that the trade relations of the world's deep trade with thesis continue to be continued. The role of the inland region is to supply commodities to the coastline; we can interpret that in the coastal region there are no important commodities produced. This article describes the trade relations that occur in the past. This is useful for the flexi trade system of the former with the present. How is the relationship between trade in the 19th century between the interior and the coast.
\end{abstract}

Keywords: Perlanja sira; trade; culture; Malay; Karo.

\section{Introduction}

In the pattern of trade relations, there is a term called the upstream and downstream trade relations. The relationship of upstream and downstream trade is trade between inland areas with coastal areas or upland and lowland areas. In its activities, trade between regions based on differences in geographical location gives rise to trade actors with certain route or path patterns, as well as commodities traded vary based on needs and commodities produced at the time, and this activity is an effort to meet the needs of one with others.

In the East Coast region of Sumatra, the pattern of trade between the interior and the coast has occurred since the pre-colonial period. Anderson in his travel records on the East Coast of Sumatra in 1823 said that inland people whom he called "Batta" had engaged in trade relations with the coast to obtain opium, salt, and clothing. ${ }^{1}$ Commodities traded on the coast of the East Coast of Sumatra in the early 16th century, according to Tom Pires, were rice, meat, wine, pepper, silk, incense, gold, slaves, etc., and of all the commodities, mostly produced from the interior. ${ }^{2}$ The role of the inland region in supplying commodities to the coastal region can be interpreted that in the coastal region no important commodity is produced. The coastal region only plays the role of an intermediary. One of the inland areas contained in the East Coast region of Sumatra is the Karo plateau. The name of this place is based on the people or ethnicities that inhabit the area. For the origin of the Karo people, there is a lot of information that explains how and where they came from. One explanation from J.H Neuwman, based on oral sources, states that the Karo people came from India, Pakpak, Dairi, Sidikalang, and Pagaruyung. ${ }^{3}$ From its origins we can know that the Karo

\footnotetext{
${ }^{1}$ John Anderson, Mission to East Coast of Sumatera in 1823, Kuala Lumpur/Singapore/New York/London: Oxford University Press, 1971, p. 250-251

${ }^{2}$ Daniel Perret, Kolonialisme dan Etnisitas: Batak dan Melayu di Sumatera Timur Laut, Jakarta: KPG, EFEO, Forum Jakarta-Paris dan Puslit Arkenas, 2010, p. 93-96.

${ }^{3}$ Ibid.,p. 45-46.
} 
people came from many regions who migrated to the Karo highlands north of Lake Toba. According to Neuman their migration continued 300 or 350 years ago, then ended 150 or 200 years ago. The distribution of Karo people is not only found in the Karo highlands, they also inhabit the lowlands in the Deli, Langkat and Serdang regions.

One important commodity that is usually needed in the interior, including the Karo region, is salt. Salt is a consumptive need that can only be obtained in coastal areas. ${ }^{4}$ For the lowlands and coastal areas, especially in Deli, the salt trade was controlled by local authorities such as the chiefs and sultans. Karo people who trade by going down to the coast to get salt and other commodities such as sniffs, gunpowder, cloth and salted fish are called by the name Perlanja Sira.

\section{Research Method}

This article uses the historical method, in the historical method one of the stages is the search for new data or sources. The search was conducted at the National Archives of the Republic of Indonesia and the National Library of the Republic of Indonesia. The method of data analysis uses the method of historical analysis which aims to study and explore facts or experiences and past developments by trying to draw conclusions and try to make interpretations of the data from the event. The main data includes data relating to the salt trade in Deli. This data collection is done to obtain documents, archives, maps, reports, and so on as reference material. In addition to written and printed sources, in writing this article also uses oral sources, namely interviewing several informants who are considered to have an understanding of the salt trade, while also interviewing residents who have traded in coastal trade.

\section{Discussion}

\subsection{Deli as a Trade Center}

Deli is one of the trade centers in East Sumatra and as a government center of the Sultanate of Deli. As the administrative center of the Deli Sultanate, Labuhan Deli also functions as a port located half a mile downstream from the river mouth. ${ }^{5}$ Upstream traders who want to sell agricultural or forest products will be subject to excise tariffs, and vice versa, traders from overseas who want to buy the commodity will also be subject to excise tariffs as well. From the results of this excise the power is formed which will eventually form the traditional Malay kingdom. ${ }^{6}$

It is this trade traffic that is transported from upstream to downstream that forms Deli as one of the traditional Malay kingdoms on the East Coast of Sumatra with Labuhan Deli as its port. Deli as a kingdom on the East Coast of Sumatra, of course, its city will be crowded. The hectic trade in Deli made many traders from outside the area trade to Labuhan Deli. These

\footnotetext{
${ }^{4}$ Ibid.,p. 101-101.

${ }^{5}$ P. J. Veth, "Het Lanschap Deli op Sumatra", TNAG, Deel II, 1877, p. 153.

${ }^{6}$ The concept of power and the formation of a traditional port were discussed by J. Kathirittamby-Wells, "Huluhilir Unity and Conflict: Malay Statecraft inEast Sumatra before the Mid-Nineteenth Century", in Archipel, 1993, p. 77-96.
} 
areas were Aceh, the Malay Peninsula and foreign traders who in the 16th century had begun to search for spices. This situation eventually formed the competition between the major powers including Aceh, Johor on the Malay Peninsula and the western nations which began with Portuguese traders.

Aceh's hegemony of ports on the East Coast of Sumatra began to loosen in the mid18th century. At that time also began to emerge ports that were previously not important to be important for suppliers of commodity trade in Malaka. One port that emerged was Deli and several other ports on the East Coast of Sumatra. ${ }^{7}$ After that, the VOC in Malacca always established good trade relations with regions or kingdoms in North Sumatra. Usually ships coming from the north of Sumatra Island, including Deli, always carry rice, pepper and others to be traded to the VOC in Malaka. ${ }^{8}$

After the VOC was dissolved at the end of the 18th century, traders continued to trade to other areas until the early 1800s, the East Coast of Sumatra began to be calculated by the British because of the large amount of pepper and other commodities traded in Penang.

In 1819, the leaders ofeli, Serdang, and Asahan opened correspondence with the British Government in Penang, which showed a desire to improve relations with the British Government in Penang. Indigenous rulers such as Deli, Serdang and Asahan considered it more profitable to establish relations with the British Government in Penang compared to the Dutch Government. ${ }^{9}$

The situation made the Government of the United Kingdom send a decision to see the conditions or conditions of the population, territory, culture, trade and agriculture. After sending a number of unsatisfactory results several times, the British Government finally resubmitted its decision in 1823, John Ansderson.

On January 16, 1823, Anderson landed at Deli. In his observations, Anderson noted that in Deli many people were already adept at making ships and boats. The largest and most complete ship is called a peddler. Besides being an expert in shipbuilding and boats, the trade in Deli is also quite busy. Many residents catch sharks (juparang) which are exported to Chinese traders for medicinal purposes. Anderson also noted the commodities exported in Deli were agricultural products and forest products. ${ }^{10}$

The agricultural and forest products exported in Deli are pepper, rice, tobacco, dried fish, gambier, camphor, wax (malem), horse, slave, sulfur, gold and elephant ivory. The imported goods entering through Labuhan Deli are various types of cloth, opium, glassware, rifles, gunpowder and salt. ${ }^{11}$ In 1822 pepper exports from Labuhan Deli had reached approximately 1,000 koyan or 26,000 bears. Whereas the rice in Deli is only for the consumption of the people themselves so that it is not exported, except when the harvest is abundant then the rice is exported. Conversely it can happen, when the weather is bad and affects the yield, Deli will import rice from surrounding areas such as Asahan and Coal. ${ }^{12}$

\footnotetext{
7 Ahmad Jaelani Halimi, Perdagangan dan Perkapalan Melayu di Selat Malaka Abad ke-15 hingga ke-18, Kuala Lumpur: Dewan Bahasa dan Pustaka, 2006, p. 86.

${ }^{8}$ ReinoutVos, Gentle Janus, Merchant Prince: The VOC and the Tightrope of Diplomacy in the Malay World, 1740-1800, Leiden: KITLV Press, 1993, p. 94-95.

${ }^{9}$ John Anderson, Acheen and the Port on the North and East Coast Sumatra, London: Wm. H. Allen \& Co. Leadenhall Street, 1840, p. 178-179.

${ }^{10}$ John Anderson, 1971, op. cit.,,p. 18-20.

${ }^{11}$ Ibid., p. 303-304.

12 Ibid.,p. 279.
} 
All commodities exported through Deli will be shipped to other regional ports such as Penang, Malacca and Singapore. Likewise, imported commodities are imported from the ports of these regions to Deli. Fully trading and shipping in Deli is run by Shah bandar. When Anderson visited, the syah bandar at Deli was held by Ahmed. It is this Syahbandar who is in charge of regulating all trades, both imports and exports. The position that quoted excise and tax at Deli was a spy, then held by a woman named Che Laut (Cik Laut). ${ }^{13}$

The placement of the first controller in Labuhan Deli J.A.M de Cats Baron de Raet has made a very profitable policy for trading in Labuhan Deli. One of the policies was to rebuild commodity storage warehouses which had previously burned down some time before their arrival. This was done solely to revive trade that had previously been crowded. ${ }^{14}$ In line with this policy many residents then built shops or stalls to enliven the week (market) again. The shops that were built were permanent using bricks and more regularly, which were located in a rattling frame, running from left to right of the road. The majority who built and occupied this place were Chinese people who had reached 1,000 people at that time. ${ }^{15}$ For approximately four years the Cats Baron de Raet became a partner in Labuhan Deli, he noted that trading activities in Labuhan Deli continued to increase, especially for forest and agricultural products. The goods imported from Deli are cloth, saltwater, while the export commodities of Deli are pepper, tobacco, rattan, sesame, nutmeg, gum, gum, gum, wax and horse. Horse trade continues to increase because inland communities (Karo) continue to intensify downstream trading relations.

\subsection{Trade Relations between Deli and the Inland}

Commodities such as horses, latex, frankincense, sulfur and wax (honey wax) are commodities carried by residents in coastal areas. ${ }^{16}$ The inland residents who carry out the Deli coastal trade are usually Karo people who in Anderson's report are called all-people. ${ }^{17}$ After making trade relations with the people on the coast, the inhabitants of the city returned by originating with imported commodities traded on the Deli coast. The merchandise is barter results with the goods they bear from the origin. The commodities carried are addicts, salt and other goods.

Trade with other areas even though the amount is very small, but plays an important role in our economy. Salt, Fish Salts, and opium are all luxury items that can all be from the coast. There are a number of other shopping activities that result in the large number of Karo residents living on the coast of East Sumatra. This is supported by the existence of an economic system called the subsistence system, which means that the Karo people must find new areas for agricultural and economic expansion ${ }^{18}$. Of these commodities, the ones most in demand by rural communities at that time were opium and salt.

\footnotetext{
${ }^{13}$ Ibid.,p. 276.

${ }^{14}$ Ratna, "Labuhan Deli: Riwayatmu Dulu", in Jurnal Historisme, Edisi No. 22/Tahun XI/ August 2006, p.9.

${ }^{15}$ J.A.M. van Cats Baron de Raet, "Vergelijking van den Vroegeren Toestand van Deli, Serdang en Langkat", TijdschrijftvoorIndischhe Taal, Land, en Volkenkunde van Bataviasch Genootshap, Deel XII, Batavia: Albrecht \& co, 1867, p. 32

${ }^{16}$ Ratna, op. cit., p. 7-8

${ }^{17}$ Anderson, op. cit., p. 308.

${ }^{18}$ Wara Sinuhaji, Aktivitas Ekonomi dan Enterpreneurship Masyarakat Karo Pasca Revolusi, Medan: USU

Press, 2004, p. 46.
} 
Opium is usually ordered by the dignitaries in Karo, such as the chiefs of the kuta, the monastery and even the head himself. There is also salt, is a very valuable item and is usually used as a food seasoning. Aside from being a seasoning, salt is also used as traditional medicine for the people of Karo. ${ }^{19}$

\subsection{Coastal Salt Trade to the Inland}

When the Cats Baron de Raet began serving in Deli, trade between the interior and the coast began to decline due to theft or robbery when traveling to the coast, as well as new sultan's regulations which were very burdensome for traders in Karo. Upon the experience, the Raets then traveled to Karo. The main purpose of Raet's trip to the highlands is to revive this trade. ${ }^{20}$ To that end, Raet held a meeting with a number of heads from the highlands accompanied by uncle Sultan Deli and vocational Senembah. Meanwhile, Raet was placed there as a controller, the sultan told the inland people that they could trade again in Deli calmly. This appeal was heard and a number of traders returned to and fro between the coast and the mountains. ${ }^{21}$

After the visit, the traders re-actively visiting the Deli on the coast. In conducting sira shopper, according to Tampak Sebayang, ${ }^{22}$ there are 6 paths that have traditionally been used by the Karo people. This path is actually also a cultural path that has traditionally been used by the Karo people for a long time to trade and stay in touch with their relatives in the Deli, Langkat, Serdang and Aceh regions. The path in detail is as follows;

- From Gadjah Village (Kampung Surbakti) -Kawar-Pamah Sembilir-Telagah-to Langkat / Binjai

- From Lau Sigedang - following the flow of the Bingai River - continue to Subekan - Tanduk Benua - to Binjai

- From Sibolangit-to the Horn of the Continent

- From the Sembahe-to the Continent Horn

- From Talun Kenas-Deli Tua-Rumah Bacang-Pancur Batu-Belawan RiverTanjung Selamat - to Sunggal.

- From Tamiang (Aceh) - Dressing up in Pura-Binjai-Namu Ukur-Tanjung Gunung-Sawit-Subeikan-Horn of Continent.

These pathways were once used as a means to carry out trade relations from coastal areas. From these pathways, then we can find out that many of these villages were formed. This indicates that in carrying out the escort, the community of the Karjugamen remained to live in the new territory.

Because it was an important commodity in the Netherlands Indies, the government did policy with the monopolization of salt. The salt monopoly was realized after the issuance of colonial government regulations with provisions relating to the prohibition of salt making,

\footnotetext{
19 The salt that was used was bulk salt which had a rather coarse texture, then after the monopoly by the colonial government the salt had to be traded in the form of briquettes. Interview with Nomi Br. Barus, 11 May 2019 at Liang's house, STM Hulu, Sumatera Utara

${ }^{20}$ Caets Baron de Raet, op. cit., p. 30.

${ }^{21}$ Daniel Perret, op. cit., p. 228-231.

${ }^{22}$ Interview with Tampak Sebayang, Former Regent of Tanah Karo 1978-1989, Padang Bulan, 5 June 2006. Tampak Sebayang is a direct descendant of Pangaring Sebayang as an asistant Nabanung Surbakti. He got information about Datuk's struggle Badiuzzazman through stories passed down from his grandmothers.
} 
except for areas mentioned as Java and Madura, West Coast of Sumatra and so on. This regulation is contained in Staatsblad Van Nelerlandsich-Indie number 73 of 1882. Behind the prohibition, there are also rules that require the making of salt for salt pond owners in monopoly areas, as well as trade and pawning salt through intermediaries of Chinese traders ${ }^{23}$

After the enactment of mopolitan cigarettes in 1882, the trading pattern of salt from the thesis in the thesis experienced a change. Initially the trade was carried out by residents of Karos themselves, but after the issuance of the policy, the trade traders had to be done by intermediaries. For the introduction of light trade in East Sumatra, the Colonial Colonial government appointed the Chinese trade attendants. This is what later the trading of salt was controlled by Chinese people through the Chinese Captain in Medan.

From the Chinese captain, then the salt is distributed by grocery stores or shops that are as special as the ones selling salt in Medan. Apart from that, the trading was also carried out immediately to the East Java and Kabanjahe. Both of these places are still traded by Chinese traders who report more than the office zoutregie in Berastagi. After reporting, then the Chin traders can continue trading to Karo traders who usually trade their trades on weekdays or don't trade on the market. Salts imported to East Sumatra are generally salted from the peninsula and Java Island. ${ }^{24}$

Since the adoption of the salt monopoly in 1882, both in terms of manufacturing and the amount of production as well as the sale is controlled by the Dutch government. For the government, salt has a high economic value. To support the salt monopoly policy, since 1915 the government has formed a regie service, known as the zoutregie dienst. One of the policies issued by the agency is the policy on salt management. In salt management, policies issued by the government are managing salt by the manufacturer, meaning that the surrounding community is prohibited from adding salt individually but must establish a factory. ${ }^{25}$

The monopolistic policy adopted by the Netherlands has actually been carried out since the days of the VOC. Some contracts entered into with various local authorities, such as with Palembang in 1662 and 1678, had the intention to guarantee monopoly. Likewise with the relationship with the Mataram authorities, in 1677, the VOC obtained monopoly rights to sell cloth and opium in the ports of Mataram. The salt monopoly policy is implemented by the government, with the consideration that the production results are an important source of revenue for the government. The profits obtained were not used for the benefit of the people in the Dutch East Indies but for the colonial government. ${ }^{26}$

Then the other policy is not allowed to sell salt in bulk. Harvested salt is then reprocessed in the form of briquettes, which are sand salts printed in the form of cubes with certain sizes, including $1 \mathrm{~kg}, 5 \mathrm{~kg}, 10 \mathrm{~kg}, 15 \mathrm{~kg}$, and $25 \mathrm{~kg}$. ${ }^{27}$ These forms of briquettes are then traded to East Sumatra including Karo. Salts in the form of briquettes which are traded to Karo are usually in the size of $1-5 \mathrm{~kg}$. These measurements can be taken by sira shoppers who buy salt in Medan or other Deli Coast, although it does not exclude the possibility that

\footnotetext{
${ }^{23}$ Staatsbald van Nederlandsch-Indie 1882 No. 73

${ }^{24}$ Regeringalmanak of 1905.

${ }^{25}$ Prawoto and Mudji Hartono, "Dampak Monopoli Garam di Madura Pada Abad XX", Mozaik Vol. 7, January 2015 , p. 31.

${ }^{26}$ Ibid.,p. 35-36.

${ }^{27}$ J. H. Abendanon, Het Zout Briketstelsel In Nederlansch-Indie, 's-Gravenhage: Martinus Nijhoff, 1907, p. $27-$ 28
} 
briquette salt measuring 10-25 kg is traded in Berastagi and Kabanjahe as a large market in Karo where salt is usually traded. ${ }^{28}$

\section{Conclusion}

In the East Coast region of Sumatra, the pattern of trade between the interior and the coast has occurred since the pre-colonial period. Anderson in his travel records on the East Coast of Sumatra in 1823 said that inland people who he called "Karau-Karau" had been trading with the coast to get opium, salt, and clothing. To receive these items, then the inhabitants of the depths do an activity called pelanja sira. Longevity is a trading activity in the past that was carried out by residents of the Karo to the coast in East Sumatra, especially Deli. One important commodity that is usually needed in the interior, including the Karo region, is salt. Salt is a consumptive need that can only be obtained in coastal areas. For lowland and coastal areas, especially in Deli, the salt trade is controlled by local authorities such as the grassroots and the Sultan. Karo people who trade by going down to the coast to get salt are called Perlanja Sira.

Pelanja sira is a very interesting research topic. From this continuation, then the people of Karom carry out Diasporas to various regions on the coast of the eastern coast such as Langkat, Deli and Sudang. From trainees to illness, they can understand how trading systems are at the height of how they are done to do the game. From this research it is expected that we will get an understanding of the spread of population in East Sumatra and the trade police in East Sumatra.

\section{Acknowledgement}

This article could not have been possible thanks to funding of "Penelitian TALENTA USU skema Penelitian Dasar" with the contract number 4167/UN5.1.R/PPM/2009 on 01 April 2019. We also thanks to Lembaga Penelitan USU which has accommodated this research. Besides that, we also thanks to Arsip Nasional Republik Indonesia because the sources of this article are widely available there.

\section{References}

Abendanon, J. H. (1907). Het ZoutBriketstelsel In Nederlansch-Indie, 's-Gravenhage: Martinus Nijhoff.

Anderson, John. (1840). Acheen and the Port on the North and East Coast Sumatra, London: Wm. H. Allen \& Co. Leadenhall Street.

(1826). Mission to the East Coast of Sumatra in 1823, Edinburgh: W, Blackwood/London, T. Cadell Strand.

Bangun, Roberto. (1989). Mengenal Orang Karo, Jakarta: Yayasan Pendidikan Bangun. Brahmaputro. (1981). Karo Dari Zaman ke Zaman, Jilid I, Medan: Ulih Saber.

\footnotetext{
${ }^{28}$ Interview with Demu Depari Sembiring 11 May 2019 in Basukum, Sibolangit, Sumatera Utara.
} 
de Raet, J.A.M. van Cats Baron, (1867) "Vergelijking van den Vroegeren Toestand van Deli, Serdang en Langkat", Tijdschrijft voor Indischhe Taal, Land, en Volkenkunde van Bataviasch Genootshap, Deel XII, Batavia: Albrecht \& co,.

Halimi, Ahmad Jaelani. (2006). Perdagangan dan Perkapalan Melayu di Selat Malaka Abad ke-15 hingga ke-18, Kuala Lumpur: Dewan Bahasa dan Pustaka.

J. Kathirittamby-Wells. (1993). "Hulu-hilir Unity and Conflict: Malay Statecraft inEast Sumatra before the Mid-Nineteenth Century", in Archipel.

Koentjaraningrat. (1982). Masyarakat dan Kebudayaan Indonesia, Jakarta: Grafiti Press

Loeb, Edwin M. (2013). Sumatera: Sejarah dan Masyarakatnya, Yogyakarta: Ombak.

Neumann, J. H. (2018). Sejarah Batak Karo Sebuah Sumbangan, Yogyakarta: Ombak.

Perret, Daniel. (2010). Kolonialisme dan Etnisitas: Batak dan Melayu di Sumatera Timur Laut, Jakarta: KPG, EFEO, Forum Jakarta-Paris dan Puslit Arkenas.

Prawoto and Mudji Hartono. (2015). "Dampak Monopoli Garam di Madura Pada Abad XX", MozaikVol. 7, January.

Ratna. (2006). "Labuhan Deli: Riwayatmu Dulu", in JurnalHistorisme, Edisi No. 22/Tahun $\mathrm{XI} /$ Agustus.

Regeringal manak tahun 1905

Staatsbald van Nederlandsch-Indie 1882 No. 73.

Sinuhaji, Wara. (2004). Aktivitas Ekonomi dan Enterpreneurship Masyarakat Karo Pasca Revolusi, Medan: USU Press.

Tamboen, P. (1952). Adat Istiadat Karo, Jakarta: Balai Pustaka.

Veth, P. J. (1877). "Het Lanschap Deli op Sumatra", TNAG, Deel II.

Vos, Reinout. (1993). Gentle Janus, Merchant Prince: The VOC and the Tightrope of Diplomacy in the Malay World, 1740-1800, Leiden: KITLV Press.

Interview with Demu Depari Sembiring 11 Mei 2019 di Basukum, Sibolangit, Sumatera Utara.

Interview with Nomi Br. Barus, 11 May 2019 di Rumah Liang, STM Hulu, Sumatera Utara.

Interview with Tampak Sebayang, Former Regent Tanah Karo 1978-1989, Padang Bulan, 5 June 2006. 